\title{
"Behavioral finance: the analysis of investor behavior based on belief and feeling and the investor rationality towards LQ 45 stocks"
}

\begin{tabular}{|c|c|}
\hline AUTHORS & $\begin{array}{l}\text { Etty Indriani iD https://orcid.org/0000-0003-0831-5229 } \\
\text { Cahyani Tunggal Sari id https://orcid.org/0000-0002-7616-8964 }\end{array}$ \\
\hline ARTICLE INFO & $\begin{array}{l}\text { Etty Indriani and Cahyani Tunggal Sari (2018). Behavioral finance: the analysis } \\
\text { of investor behavior based on belief and feeling and the investor rationality } \\
\text { towards LQ } 45 \text { stocks. Investment Management and Financial Innovations, 15(1), } \\
\text { 292-298. doi: } 10.21511 / \text { imfi.15(1).2018.24 }\end{array}$ \\
\hline DOI & http://dx.doi.org/10.21511/imfi.15(1).2018.24 \\
\hline RELEASED ON & Friday, 16 March 2018 \\
\hline RECEIVED ON & Friday, 15 December 2017 \\
\hline \multirow[t]{2}{*}{ ACCEPTED ON } & Thursday, 22 February 2018 \\
\hline & $($ (c) $)$ EY-NC \\
\hline LICENSE & $\begin{array}{l}\text { This work is licensed under a Creative Commons Attribution-NonCommercial } 4.0 \\
\text { International License }\end{array}$ \\
\hline JOURNAL & "Investment Management and Financial Innovations" \\
\hline ISSN PRINT & $1810-4967$ \\
\hline ISSN ONLINE & $1812-9358$ \\
\hline PUBLISHER & LLC "Consulting Publishing Company "Business Perspectives" \\
\hline FOUNDER & LLC "Consulting Publishing Company "Business Perspectives" \\
\hline
\end{tabular}

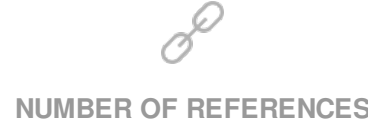

14
NUMBER OF FIGURES

0
ニニ:

NUMBER OF TABLES

6

(C) The author(s) 2022. This publication is an open access article. 


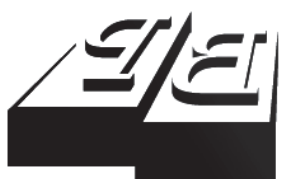

BUSINESS PERSPECTIVES

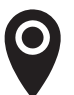

LLC "CPC "Business Perspectives" Hryhorii Skovoroda lane, 10, Sumy, 40022, Ukraine

www.businessperspectives.org

Received on: $15^{\text {th }}$ of December, 2017 Accepted on: 22 $2^{\text {nd }}$ of February, 2018

(C) Etty Indriani,

Cahyani Tunggal Sari, 2018

Etty Indriani, Ph.D. (Finance Management), Department of Economic, STIE AUB Surakarta College, Indonesia.

Cahyani Tunggal Sari, S.E., MM. (Finance Management), Department of Economics, STIE AUB Surakarta College, Indonesia.

\section{(ㄷ)(1) $(8$}

This is an Open Access article, distributed under the terms of the Creative Commons Attribution-NonCommercial 4.0 International license, which permits re-use, distribution, and reproduction, provided the materials aren't used for commercial purposes and the original work is properly cited.
Etty Indriani (Indonesia), Cahyani Tunggal Sari (Indonesia)

\section{BEHAVIORAL FINANCE: THE ANALYSIS OF INVESTOR BEHAVIOR BASED ON BELIEF AND FEELING AND THE INVESTOR RATIONALITY TOWARDS LQ 45 STOCKS}

\begin{abstract}
This research analyzes behavioral finance, especially the behavior of investors in Yogyakarta, Indonesia Region. The performance of investor behavior is examined based on the LQ 45 stocks return on Indonesia Stock Exchange and questionnaires that are spread out to five securities agents in Yogyakarta.

The performance of LQ 45 stocks return is compared to the questionnaire analysis in the "Belief" part at the first and second stages. The first result shows that LQ 45 stocks are profitable. It can be seen from the average return of the stocks that it has positive value and is statistically identical with the LQ 45 index return. This result is in line with the investors' opinion that LQ 45 stocks are profitable. The second result shows that most of LQ 45 stocks are profitable and give high return. But, this result is also contrary to the opinion of investors towards traditional finance paradigm that investors still believe "high risk - high return, low risk - low return". Although most of LQ 45 stocks are considered as low risk stocks, many investors prefer to choose LQ 45 stocks. It means that the traditional finance paradigm has weakness. It is proven that investors sometimes act irrationally.
\end{abstract}

The third and fourth stages of the study are aimed to analyze the relationship between feeling and belief towards frequency of transaction each day based on the questionnaire using regression analysis. The result shows that there is significant relationship between feeling and frequency of transaction each day.

\section{Keywords investor behavior, LQ 45 stocks, belief, feeling \\ JEL Classification G02, G11}

\section{INTRODUCTION}

Traditional finance theory seems very simple. The basic fact of aggregate stock market, the cross-sections of average returns, and individual trading behavior in this research is not easy to understand.

In order to cover the weakness of traditional finance theory, there appears a new paradigm called behavioral finance. Behavioral finance is a new approach to financial market that has emerged, at least in part, in order to response the difficulties of traditional finance paradigm. Behavioral finance argues that some financial phenomena can plausibly be understood using models in which some agents are not fully rational. The field has two building blocks: limits to arbitrage, which argues that it can be difficult for rational traders to revise the dislocations caused by less rational traders; and psychology, which classifies the kinds of deviations from full rationality we might expect to see. Behavioral economists typically turn to the extensive experimental evidence compiled by cognitive psychologists on the biases that arise when they make the decision, they remember their beliefs or by people's preference. 
Arbitrageurs would show the investor who are trading and move ahead from others (Delong et al., 1990; Abreu \& Marcus, 2002, 2003). Goetzmann and Massimo (1999) find a strong index fund flows in line with daily index returns. While Edelen and Warner (2001) find evidence of mutual fund flows following returns.

Investors misjudged gains in wealth to their ability to pick stocks. As a result, they underestimate the variance of stock returns and trade more frequently in subsequent periods because of inappropriately tight error bounds around return forecast. Turnover of U.S. market is positively related to the lag market return in trading volume measure (Statman et al., 2006).

Using a sample of 3,000 individual investors over a 51-month period, Markus and Martin (2007) find that both past market return and past portfolio returns affect trading activity of individual investors (as measured by stock portfolio turnover, the number of stock transactions, and the probability to trade stocks in a given month). They presented evidence that individual investors, on average, are unable to give a correct estimate of their own past realized stocks portfolio performance.

Considering the controversial argument surrounding the issue related with behavioral finance and investor overconfidence, the writer decides to explore and investigate the issue empirically and in more depth on LQ 45 stocks listed on the Indonesia Stock Exchange (IDX). This study aims at analyzing the investor behavior based on belief and feeling and the investor rationality towards LQ 45 stocks.

\section{LITERATURE REVIEW AND HYPOTHESES DEVELOPMENT}

Behavioral finance argues that asset prices are interpreted as deviations that brought by the presence of traders who are not fully rational. Any disallocation caused by irrational traders will be revised by rational traders (Friedman, 1953).

There are two assertions from Friedman's argument. First, as soon as there is a deviation from the fundamental value, attractive investment opportunities are created. Secondly, with opportunities there will be correction by rational traders. Financial behavior does not take issue to the second step in this argument, where the emergence of attractive investment opportunities is not exploited quickly (Friedman, 1953).

Thought of financial terminology is very interesting in this research. Rational traders are often referred to as "arbitrageurs". In fact, arbitration is an investment strategy that offers fewer benefits at no cost. Rational traders known as arbitration create opportunities to reduce the risk of profit. Financial behavior argues that a rational merchant strategy does not have to be arbitration; it is just quite frequent and very risky (Friedman, 1953).

\subsection{Excessive trading}

The most prominent behavioral explanation of over-confident trading is where people believe that information circulating in the market is too weak. This hypothesis predicts that people are more confident to trade more often. Barber and Odean (2000) show that investors who trade the most are those who gain the lowest average rate of return.

Individual investors are beginning to shift from a phone-based trade to an online trade with increased trust. This increase in trust is due to better access to information and a higher level of control. In addition to this, the yields of investors who switched are higher thanthe yields of investors who still survive the old method (Barber \& Odean, 2002).

\subsection{The selling decision}

Several studies find that investors are reluctant to sell assets, trading at a loss relative to the price at which they were purchased, this phenomenon is called "disposition effect" (Shefrin \& Statman, 1985). Working with the same discount brokerage data used, Odean (1999) finds that the individual investors are more likely to sell stocks which have gone up in value relative to their purchase price, rather than stocks 
which have gone down. Two behavioral explanations of these findings have been suggested. First, investors may have an irrational belief in mean-reversion. Second, possibility relies on prospect theory and narrow firming. This time it is not loss aversion that is central, but rather the concavity (convexity) of the value function in the region of gains (loses).

The behavior of professional traders on the Treasury Bond futures pit at the CBOT proves that traders with a gain (loss) in mid-day trading will take more risk in their afternoon trade (Coval \& Shumway, 2000).

The momentum of stock returns makes investor behavior inherent in the disposition effect in a dubious position. Investors who have benefited will be interested in selling shares. Selling pressure that initially can suppress the stock price, will result in higher yields later on. On the other hand, if shareholders face capital losses, they will only sell if there is a premium price offer. Therefore, an increased price will result in lower profits. Stock returns in the last 12 months and also on the size of the capital gains or losses faced by holders. Variable capital gain or loss steals large amounts of explanatory power from the past (Grinblatt \& Han, 2001).

Based on the literature review and related studies above, the hypotheses are concluded as follows.

\section{H1: The LQ 45 index represent all the LQ 45 stocks observed.}

When the return of the index can represents all the observation data, it means that based on the index we can predict and analyze all stocks. Besides, it also means that the investors receive all information about the stocks.

This research also analyzes whether the stocks are always profitable. If the average return of the stock is positive, it means that it is profitable. That result is also compared to the investors opinion about the statement of "the stocks are always profitable" in the questionnaire.

H2: The LQ 45 stocks always give high return to their investors.
The LQ 45 stocks is the 45 most liquid stocks on Jakarta Stock Exchange. It means that many investors buy and sell these stocks because they think that all the LQ 45 stocks are profitable and offer high return compared to other stocks. This research analyzes whether the LQ 45 stocks always give high returns and based on traditional paradigm which states that, if the stock gives high return, it has high risk too. What about the LQ 45 stocks? Are they having high risk and high return? Besides, this research also examines whether the opinion of the investors is similar to the statistical result based on the investor answer in the belief part of the questionnaire: "high risk - high return" and "the LQ 45 stocks are always profitable" compared to the statistical result using the normal distribution.

If the stocks are not considered as high return stocks and the investors still choose these stocks on investment, it means that the investors are influenced by other factors non empirically (such as return) but the psychological effect that cannot be predicted (such as belief, feeling, overconfidence), the factors that come from the company, and many other empirical factors. Besides, if the stocks do not follow the traditional rule "high risk - high return", when the investors said that the stocks having high return also have high risk, it means that investors still believe the traditional paradigm. The fact, the market is different from what the investors thought; sometimes investors do differently and contrary to its thinking. They act irrationally in the market.

H3: There is a relationship between belief and frequency of transactions.

If there is a relationship between belief and frequency of transactions, it means that the market is in unfavorable conditions and there physiological effect on the investors in investment decision making.

\section{H4: There is a relationship between feeling and frequency of transactions.}

If there is a relationship between feeling and frequency of transactions, it means that the market is in unfavorable conditions and there is physiological effect on the investors in investment decision making. 


\section{METHODOLOGY}

The following are the characteristics of data used in this research.

- Price index of LQ 45 stocks on the Indonesia Stocks Exchange for the period of January 1, 2003 till December 31, 2005.

- Daily closing prices of stocks on the Indonesia Stocks Exchange which are the member of LQ 45 stocks for the period of January 1, 2003 till December 31, 2005.

- Individual data set of investors who are actively trading for the period of March 2005 till May 2005.

\subsection{Data analysis method}

\section{Independent sample $t$-test}

This research uses independent sample t-test in order to test the mean of two samples that are unrelated or independent. The main idea of this test is to analyze whether there is difference of means between two sample populations by seeing the men of two samples.

\subsection{Multiple linear regression}

The purpose of multiple regression analyses is to calculate multiple regression equation, statistical association with scatter plot, colinearity diagnosis, prediction price and residual. This research, uses two independent variables. So, it uses the multiple linear regression equation models.

$$
Y=a+b X_{1}+c X_{2}
$$

where $Y$ - transaction frequency, $a$ - constant, $b$ - regression coefficient of feeling, $c$ - regression coefficient of belief, $X_{1}$ - feeling, $X_{2}$ - belief.

\section{RESULT}

\section{The steps in computing data are as follows.}

The data on investor behavior that are belief and feeling is taken from the 39 investors who are actively doing transaction and follow the movement of stock rate in the stock gallery in Yogyakarta. The sample of the stocks and index is taken from 14 companies that are listed on the Indonesia Stock Exchange. The data is daily data since January 1, 2003 until December 31, 2005. So, the total data of stocks is 783 .

\section{Calculating the average return}

The average return is calculated by mathematical function (average):

$$
\text { Average }=\operatorname{average}\left(R_{i}, t\right) \text {. }
$$

The average return of each sampled firm is shown in Table 1.

Table 1. Average return for each LQ 45 stock and LQ 45 index

\begin{tabular}{l|c}
\hline \multicolumn{1}{c|}{ Stocks } & Average return \\
\hline INDF & 0.0005 \\
\hline KIJA & 0.0007 \\
\hline CMNP & 0.0009 \\
\hline PNBN & 0.0011 \\
\hline GJTL & 0.0011 \\
\hline MEDC & 0.0012 \\
\hline ADMG & 0.0014 \\
\hline PTBA & 0.0014 \\
\hline ASII & 0.0015 \\
\hline SMCB & 0.0015 \\
\hline BLTA & 0.0019 \\
\hline INTP & 0.0021 \\
\hline ANTM & 0.0023 \\
\hline LSIP & 0.0032 \\
\hline LQ 45 INDEX & 0.0014 \\
\hline
\end{tabular}

From the results of average return above, we can see that the highest return is 0.0032 for the LSIP stock and the lowest average return is 0.0005 for INDF. While the LQ 45 index is 0.0014 .

Based on the result above, the return of LQ 45 stocks is positive and it means that the LQ 45 stocks are profitable. This result is consistent with the second hypothesis that most of investors agree that the LQ 45 stocks are profitable.

The first hypothesis is intended to analyze whether LQ 45 index returns on the Indonesia Stock Exchange represent the LQ 45 stocks return by analyzing the difference of its mean. The result of the independent sample $t$-test is as follows. 
Table 2. Independent sample t-test result between average LQ 45 stock return and average LQ 45 Index return

\begin{tabular}{c|c|c|c|c}
\hline Value & $\mathbf{N}$ & $\mathbf{F}$ & Sig. F & $\begin{array}{c}\text { Significance } \\
\text { 2-tailed }\end{array}$ \\
\hline Index return & 726 & 2.081 & 0.15 & 0.994 \\
\hline Stock return & 14 & - & - & 0.956 \\
\hline
\end{tabular}

Based on the result above, we can conclude that the significance value of equal variances assumes (0.994) is higher than the probability value $(0.05)$. It means that $\mathrm{H} 01$ is accepted and the conclusion is that the means of LQ 45 stocks return and LQ 45 index return are identical. So, based on the LQ 45 index, investors can predict the situation of LQ 45 stocks.

Calculating the standard deviation

$$
\text { Standard deviation }=\operatorname{STDEV}\left(R_{i}, t\right) .
$$

Table 3. Standard deviation for each LQ 45 stock and LQ 45 index

\begin{tabular}{l|c}
\hline \multicolumn{1}{c|}{ Stocks } & Standard deviation \\
\hline INDF & 0.025 \\
\hline KIJA & 0.026 \\
\hline CMNP & 0.0266 \\
PNBN & 0.0274 \\
GJTL & 0.0274 \\
\hline MEDC & 0.029 \\
\hline ADMG & 0.0302 \\
\hline PTBA & 0.0311 \\
\hline ASII & 0.0316 \\
\hline SMCB & 0.0369 \\
\hline BLTA & 0.0368 \\
\hline INTP & 0.5251 \\
\hline ANTM & 0.054 \\
LSIP & 0.2701 \\
\hline LQ 45 INDEX & 0.0425 \\
\hline
\end{tabular}

From the result of average return above, we can see that the highest standard deviation is 0.5251 for the INTP stock and the lowest standard deviation is 0.025 for INDF. While the standard deviation of LQ 45 index is 0.0425 .

Although most of LQ 45 stocks are of low risk, their return is not always low. Out of the 14 companies of LQ 45 stocks observed, 7 stocks are considered as low risk and high return, 6 stocks are considered as low risk and low return, and 1 stock is considered as high risk and low return. So, based on the second hypothesis, $H O$ is supported: LQ 45 stocks are low risk stocks and it is similar with the theoretical framework that the LQ 45 are considered as blue-chips stocks and they are usually considered as low risk stocks and many investors prefer these stocks over others.

This result is in contrast to the investor's opinion towards the statement "high risk - high return, low risk - low return". Most investors totally agree with that statement, it means that investor's believes and thoughts are not in line with what they do in the market. Although they know that the low risk stocks do not give them high return, they still prefer the lower risk stocks. It means that sometimes investors act irrationally. So, most of the investors tend to be risk averse than risk takers because they prefer the low risk stocks over the high risk stocks.

Table 4. Descriptive statistics

\begin{tabular}{l|c:c:c}
\hline \multicolumn{1}{c|}{ Variable } & Mean & $\begin{array}{c}\text { Standard } \\
\text { deviation }\end{array}$ & $\mathbf{N}$ \\
\hline $\begin{array}{l}\text { Transaction } \\
\text { frequency on each } \\
\text { day }\end{array}$ & 19.6154 & 3.81559 & 39 \\
\hdashline Feeling & 26.1538 & 5.72868 & 39 \\
\hdashline Belief & 24.1026 & 3.71196 & 39 \\
\hline
\end{tabular}

The result shows the description of all the variables: the $Y$ variable (transaction frequency in a day) as a dependent variable, $X_{1}$ variable (feeling), and $X_{2}$ (belief) as an independent variable. The descriptive statistics table consists of means, standard deviation, and the amount of cases. Table 4 shows that the transaction frequency variable a day has mean of 19.6154, standard deviation of 3.81559 and the amount of cases $(N)$ is 39 , and so the other variables, belief and feeling.

Table 5. Model summary

\begin{tabular}{c|c}
\hline R-value & R-square \\
\hline 0.563 & 0.317 \\
\hline
\end{tabular}

The value of $R$ that reflects the combined correlation of two independent variables $X_{1}$ and $X_{2}$ towards $Y$ is 0.563 . The $R_{2}$ is 0.317 that reflects the $31.7 \%$ of $Y$ variable is influenced by the $X_{1}$ and $X_{2}$ variables. The rest $(=68.3 \%)$ is influenced by the other factor. 
Table 6. Coefficient

\begin{tabular}{l|c|c|c|c}
\hline \multicolumn{1}{c|}{ Variable } & Constant & Significance level & a & Result \\
\hline Transaction frequency on each day & 8.817 & 0.028 & 0.05 & Significant \\
Feeling & 0.367 & 0 & 0.05 & Significant \\
Belief & 0.04963 & 0.734 & 0.05 & Not significant \\
\hline
\end{tabular}

\section{CONCLUSION}

The returns of LQ 45 stocks are positive and it means that the LQ 45 stocks are profitable. This result is in line with the investors opinion of the second statement on the questionnaire in "Belief" part that most of investors agree that the LQ 45 stocks are profitable.

Although most of LQ 45 stocks are considered as low risk stocks, many investors prefer to choose LQ 45 stocks. It means that the traditional finance paradigm has weakness. It is proven that investors sometimes act irrationally.

The result of the multiple linear regressions had proven that the transaction frequency is significantly influenced by feelings of the investors.

\section{RESEARCH LIMITATIONS AND FURTHER RESEARCHES}

The limitations and suggestions from this research are as follows:

1. This research uses LQ 45 stock companies on the Indonesia Stocks Exchange. Further research can be done by using another type of stocks in the Jakarta Stocks Exchange.

2. The further research can be done by using different methods and different analyses to determine the LQ 45 stocks risk and return in the short run and in the long run.

3. The usage of LQ 45 index as a comparison to determine the long-term return has weakness because not all the LQ 45 stocks are included in this research. Further research can also use the Indonesia Composite Index (IHSG) for determining the long term return.

4. The further research can be done by using the other investor behavior such as the image of the company, gender, mood, and other internal factors of individual investors.

5. This research only covers the respondents studying at college or university and investing in capital market through stock agents in Yogyakarta. Further research can take respondents living not only in Yogyakarta and having other educational status.

\section{REFERENCES}

1. Abreu, Dilip, \& Marcus, K. B. (2002). Synchronization Risk and Delayed Arbitrage. Journal of Financial Economics, 66(2-3), 341-360.

2. Abreu, Dilip, \& Marcus, K. B. (2003). Bubbles and Crashes. Econometrica, 71(1), 173-204.
3. Barber, B. M., \& Odean, T. (2000). Trading is Hazardous to Your Wealth: the Common Stock Performance of Individual Investors. Journal of Finance, 55(2), 773-806. https://doi. org/10.1111/0022-1082.00226

4. Barber, B. M., \& Odean, T. (2002). Online Investors: Do the slow die first? The Review of Financial Studies, 15(2), 455-487.

5. Coval, J., \& Shumway, T. (2000). Do behavioral biases affect prices? Working Paper (University of Michigan, Ann Arbor, MI).

6. Delong, J. B., Shleifer, A. Summers L., \& Waldmann, 
R. J. (1990). Positive Feedback Investment Strategies and Destablizing Rational Speculation. The Journal of Finance, 45(2), 379-395.

7. Edelen, Roger M., \& Jerold, B. Warner (2001). Aggregate Price Effects of Institutional Trading: A study of Mutual Fund Flow and Market Returns. Journal of Financial Economics, 59(2), 195-220.

8. Friedman, M. (1953). The Case of Flexible Exchange Rates. Essays in Positive economics. Chicago: University of Chicago Press.
9. Grinblatt, M., \& Han, B. (2001). The disposition effect and momentum (Working Paper) University of California, Los Angeles, CA.

10. Markus, G., \& Martin, W. (2007). Which Past Return Affect Trading Volume. Retrieved from http://ssrn.com/ abstract $=686802$

11. Goetzmann, William, \& Massimo, M. (1999). Index Funds and Stock Market Growth. (Working paper). Yale University.
12. Odean, Terrance (1999). Do Investors Trade Too Much? American Economic Review, 89(5), 1279-1298. https://doi. org/10.1257/aer.89.5.1279

13. Shefrin, H., \& Statman, M. (1985). The Disposition To Sell Winners Too Early and Ride Losers Too Long: Theory and Evidence. The Journal of Finance, 40(3), 777-790.

14. Statman, M, Thorley, S Vorkink, K. (2006). Investor Overconfidence and Trading Volume. The Review Financial Studies, 19(4), 1531-1565. 